\title{
Antimicrobial Action of Epidermal Mucus Extract of Clarias gariepinus (Burchell, 1822) Juveniles-Fed Ginger Inclusion in Diet
}

\author{
A. A. Nwabueze ${ }^{1}$ \\ ${ }^{1}$ Department of Fisheries, Delta State University, Asaba Campus, Nigeria \\ Correspondence: A. A. Nwabueze, Department of Fisheries, Delta State University, Asaba Campus, Asaba, \\ Nigeria. E-mail: aanwabueze@gmail.com
}

Received: December 13, 2013

Accepted: January 16, 2014 Online Published: January 26, 2014

doi:10.5539/ijb.v6n2p42

URL: http://dx.doi.org/10.5539/ijb.v6n2p42

\begin{abstract}
The antimicrobial activity of epidermal mucus extract of $C$. gariepinus juveniles-fed ginger inclusion in diet was investigated and compared with the activity of epidermal mucus extract of $C$. gariepinus juveniles (control) without ginger in diet. This study demonstrates the antimicrobial role of ginger in improving protection of fish against bacterial infection as shown by the higher zones of inhibition observed for epidermal mucus extract of fish-fed ginger in diet as compared with control. Zones of inhibition for epidermal mucus of treatment fish were $30.7 \mathrm{~mm}, 29.8 \mathrm{~mm}, 26.3 \mathrm{~mm}$ and $19.3 \mathrm{~mm}$ for Bacillus, Escherichia, Staphylococcus and Streptococcus species respectively. Though these values were not significantly $(\mathrm{P}>0.05)$ higher than those obtained for the control fish with zones of inhibition of $25 \mathrm{~mm}, 11.2 \mathrm{~mm}, 9.0 \mathrm{~mm}$ and $7.3 \mathrm{~mm}$ for Bacillus, Escherichia, Staphylococcus and Streptococcus species respectively, the higher values recorded for the treatment fish shows that ginger inclusion in fish diet had an antibiotic effect against isolates of bacteria in fish samples from cultured ponds. The addition of ginger in C. gariepinus diet is encouraged as its action is indicative of the potentials of ginger in preventing emergence of resistant bacteria and improving the antimicrobial role of fish mucus and therefore the quality of $C$. gariepinus.
\end{abstract}

Keywords: antimicrobial, Clarias gariepinus, epidermal mucus, ginger

\section{Introduction}

\subsection{The Problem}

All fish live in microbe-rich environment and are vulnerable to invasion by pathogenic and opportunistic micro-organisms. The environment of fish being aquatic is very challenging with fish in constant interaction with a wide range of pathogenic and non-pathogenic micro-organisms (Subramanian, Mackinnon, \& Ross, 2007). Environmental degradation due to pollution of natural water bodies and poor culture conditions of some culture fish ponds have elicited the presence of these pathogenic agents (Nwabueze, 2011,2012) with bacteria being one of the most common micro-organisms of farmed catfishes.

\subsection{Importance of the Problem}

Fish is sometimes overwhelmed by these pathogenic agents and sometimes succumb to infections. In culture ponds, especially in the tropics, a number of antimicrobial agents have been used to combat several diseases of fish. In recent times though, an increase in the antibiotic resistant strains of some of these micro-organisms have been observed. Antimicrobial activity has been demonstrated in fish mucus of several fish species, yet this activity seems to vary from fish species to species such as rock fish (Sebastes schlegelii), rainbow trout (Oncorhynchs mykiss) and tilapia (Tilapia hornorum) and can be specific toward certain bacteria (Noya, Magarinos, Toranzo, \& Lamas, 1995). Clarias gariepinus is a valuable farmed food fish in Nigeria. Its high nutrition and importance in aquaculture have encouraged a lot of researches in the improvement of the quality of the fish species.

\subsection{Relevant Scholarship}

Increase in antibiotic resistance of some microbial strains has lead to investigations on the use of traditional plants for their antibacterial and medicinal values (Bhalodia \& Shukla, 2011). Fishes produce mucus from the epidermal cell layer for protection against some of these pathogenic agents in the aquatic medium. Fish epidermal mucus has been reported to be a component of innate immunity playing an important role in the 
prevention of colonization by parasites, bacteria and fungi (Muroga, Higashi, \& Keitoku, 1987; Kanno, Nakai, \& Maroga, 1989; Ebran, Julien, Orange, Auperin, \& Molle, 2000). Fish epidermal mucus has also been known to contain a variety of biologically active compounds and antimicrobial peptides that are constitutively expressed to provide immediate protection of fish from potential pathogenic microbes and parasites (Hjelmeland, Christe, \& Raa, 1983). Kasai, Ishikawa, Komata, Fukuchi, Chiba, Nozaka, Nakamura, Sato and Miura (2009) reported an antibacterial protein 1-amino acid oxidase (LAAO) from the epidermal mucus of flounder Platichthys stellatus which exerted antibacterial activity against Staphylococcus epidermids, S. aureus and methicillin-resistant $S$. aureus. It has also been noted that this antibacterial protein exerted antibacterial activity in a variety of animal fluids such as snake venom (Du \& Clemetson, 2002), fish epidermal mucus and extract (Jung, Mai, Iwamoto, Arizono, Fujimoto, Sakamaki, \& Yonehara, 2000; Kitani et al., 2007; Kitani, Kikuchi, Zhang, Ishizaki, Shimakura, Shiomi, \& Nagashima, 2008) body surface mucus of the giant African snail (Obara, Otsuka-Fuchino, Sattayasai, Nonomura, Tsuchiya, \& Tamiya, 1992). It is therefore important to consider ways of improving fish health by using biological agents to prevent infections rather than using drugs to provide cure. Ginger plant is a spice that has been noted for its medicinal values as an analgesic, sedative, antipyretic and antibacterial agent (Patrick-Iwuanyanwu, Wegwu, \& Ayalogu, 2007). Ginger also has anti-microbial, anti-oxidative and seasoning qualities.

\subsection{Hypothesis}

This study examines the antimicrobial activity of epidermal mucus extract of $C$. gariepinus-fed ginger inclusion in diet, to know if ginger can enhance protection in fish as expressed by the epidermal mucus extract of cultured C. gariepinus.

\section{Materials and Methods}

\subsection{Study Area}

The antibiotic activity of epidermal mucus extract of $C$. gariepinus (average weight of $40.6 \pm 0.1 \mathrm{~g}$ and total length of $17.2 \pm 0.4 \mathrm{~cm}$ ) juveniles-fed ginger inclusion in diet was investigated from January to May, 2013 at the Department of Fisheries and Faculty of Agriculture Research Laboratories of Delta State University, Asaba Campus, Asaba, Nigeria.

\subsection{Acclimation and Experimental Tanks}

Sixty juvenile fish were obtained from the Faculty of Agriculture Research Farm and acclimated for 7 days in stock tank during which time fish were fed commercially available feed at $4 \%$ body weight. Stock tank $(45 \mathrm{~cm} \times$ $45 \mathrm{~cm} \times 90 \mathrm{~cm}$ ) was well aerated and contained 50 litres of borehole water, tank water temperature was $26.4{ }^{\circ} \mathrm{C}$ and tank water was changed twice. Ten apparently healthy fish samples each distributed into two smaller tanks $(40 \mathrm{~cm} \times 40 \mathrm{~cm} \times 60 \mathrm{~cm})$ containing 25 litres of water and labelled, A (control) and B (Treatment) with two replicates of $\mathrm{A}_{1}, \mathrm{~A}_{2}$ and $\mathrm{B}_{1}, \mathrm{~B}_{2}$ making up a total of 60 C. gariepinus fish were used.

\subsection{Preparation of Experimental Diet}

Ginger root was bought from a local market in Asaba, back was peeled off and $100 \mathrm{~g}$ ginger was cut into bits and sun-dried for 5 days and later ground into powder form using an electric blender, sieved and stored in container away from moisture and direct sun light according to Stoll (2000) until further use. Fish in experimental tanks were fed formulated diet with fish in the treatment tanks $\mathrm{B}, \mathrm{B}_{1}$ and $\mathrm{B}_{2}$ having an addition of $0.5 \%(0.025 \mathrm{~kg})$ inclusion of ginger in fish diet (Table 1). Fish were fed for 4 months after which the epidermal mucus extract of fish in control and treatment tanks were collected and examined for their antimicrobial activities. 
Table 1. Composition of experimental diets

\begin{tabular}{cccc}
\hline Ingredients & Control diet composition $(\mathrm{kg})$ & Treatment diet composition $(\mathrm{kg})$ & Concentration of diets (\%) \\
\hline Groundnut cake & 0.78 & 0.75 & 15.0 \\
Soya bean & 0.78 & 0.75 & 15.0 \\
Fish meal & 0.78 & 0.75 & 15.0 \\
Vitamin C & 0.026 & 0.025 & 0.50 \\
Bone meal & 0.21 & 0.20 & 4.0 \\
Premix & 0.10 & 0.10 & 2.0 \\
White maize & 0.52 & 0.50 & 10.0 \\
Wheat (rice & 0.52 & 0.50 & 10.0 \\
bran) & 1.46 & 1.4 & 28 \\
Palm oil & - & 0.025 & 0.50 \\
*Ginger & & &
\end{tabular}

*Added only for fish in treatment tanks.

\subsection{Isolation and Identification of Bacteria Isolates}

Bacterial isolates were obtained from epidermal mucus of apparently healthy 6 months old live C. gariepinus fish weighing about $480 \mathrm{~g}$, harvested from a culture pond in Asaba. Mucus samples were carefully and aseptically scraped from the dorsal surface of fish skin using a sterile soft rubber spatula. The aqueous mucus scrapings were pooled and cultured on Sabourand Dextrose agar at $37{ }^{\circ} \mathrm{C}$ for $24 \mathrm{~h}$. Distinct growth colonies observed were sub cultured into sterile Petri dishes with Nutrient agar by streaking method to obtain pure isolates which were incubated aerobically at $37^{\circ} \mathrm{C}$ for $24 \mathrm{~h}$. A growing edge of distinct isolates was picked from pure cultures and streaked with inoculating loop onto sterile Petri dish with Nutrient agar as the growth medium for each of the isolates. Isolates were identified using routine Gram Staining Techniques and Biochemical Characterization according to MacFaddin (1980). Bacterial isolates obtained were Staphylococcus, Streptococcus , Escherichia and Bacillus species. Each pure colony was suspended in physiological saline $(0.85 \% \mathrm{NaCl})$ and standardized to correspond to $1.5 \times 10^{8} \mathrm{CFU} / \mathrm{ml}$ of each bacterial isolates.

\subsection{Preparation of Plate Inoculums}

Fresh sterile cotton-tipped swap was dipped into suspension of pure bacterial isolates and was used to inoculate sterile Mueller-Hinton Agar plates by streaking and ensuring even distribution of the inoculums. This was done for each bacterial isolates.

\subsection{Collection and Sterilization of Fish Epidermal Mucus}

Mucus from the control and experimental fish samples was carefully scraped from the anterior to the posterior of the dorsal body using a sterile soft rubber spatula. Mucus scrapings were pooled from the ten experimental and also pooled from the ten control fish separately. Mucus samples were then thoroughly mixed with equal quantity of sterilized physiological saline $(0.85 \% \mathrm{NaCl})$ and centrifuged at $5000 \mathrm{rpm}$ for 15 minutes according to kuppulakshmi, Prakash, Gunasekaran, Manimealai and Sarojini (2008). The supernatant was collected and stored at $4{ }^{\circ} \mathrm{C}$ and were used to prepare the antibiotic disc for the antimicrobial studies.

\subsection{Preparation of Antibiotic Disc}

Sensitivity disc was prepared employing pipette delivery to impregnate $20 \mu \mathrm{l}$ of the epidermal mucus extract of control and treatment $C$. gariepinus fish onto a disc using disc diffusion method (Cavalieri et al., 2005). Discs were firmly pressed down to ensure complete level contact with agar.

\subsection{Sensitivity Testing}

After the introduction of the disc, the plate was allowed to incubate at $37^{\circ} \mathrm{C}$ for $24 \mathrm{~h}$. Zones of inhibitions were measured to the nearest millimetres. Sensitivity testing was carried out on epidermal mucus extract of fish from control and treatment tanks on the bacterial lawn for the different isolates. A clear zone of inhibition (plaque) indicates absence of bacterial growth while no discernable plaque around the disc, means that the bacteria are growing normally. The presence of a plaque means sensitivity while the absence of a plaque means resistance. 


\subsection{Statistical Analysis}

Student ' $t$ ' test statistic was employed to analyze data collected for zones of inhibition of the four different strains of bacteria isolated from the fish epidermal mucus from both the control and treatment tanks. Differences between means were considered significant when $P<0.05$.

\section{Results}

Bacterial isolates used for this study were Staphylococcus, Streptococcus, Escherichia and Bacillus species. All bacteria isolates were sensitive to epidermal mucus extract of fish from both control and treatment experiments. Zones of inhibition of epidermal mucus extract of control and treatment fish against bacterial isolates are presented in Table 2. The resulting zones of inhibition for epidermal mucus of treatment fish were $30.7 \mathrm{~mm}, 29.8$ $\mathrm{mm}, 26.3 \mathrm{~mm}$ and $19.3 \mathrm{~mm}$ for Bacillus, Escherichia, Staphylococcus and Streptococcus species respectively. While for the control fish values of $25 \mathrm{~mm}, 11.2 \mathrm{~mm}, 9.0 \mathrm{~mm}$ and $7.3 \mathrm{~mm}$ were zones of inhibition for Bacillus, Escherichia, Staphylococcus and Streptococcus species respectively. Bacillus species was observed to be more sensitive to the activity of ginger than the other isolates. Streptococcus species was the least sensitive. The same trend was also observed for epidermal mucus of the control fish.

Zones of inhibition were observed to be higher in the epidermal mucus of fish-fed ginger inclusion in diet as compared with epidermal mucus of control fish without ginger in diet. Zones of inhibition of the four different strains of bacteria isolated from fish epidermal mucus from both the control and treatment tanks were analyzed separately. Results of analysis however show that there were no significant difference $(P>0.05)$ in the zones of inhibition of epidermal mucus of control fish as compared with the epidermal mucus of treatment fish (Table 3). In this study, the mucus extracted from C. gariepinus (control fish) showed inhibitory effect on selected bacteria isolates. However, C. gariepinus-fed ginger in diet had more inhibitory effect on the selected bacteria isolates.

Table 2. Zones of inhibition of epidermal mucus of $C$. gariepinus against bacteria isolates

\begin{tabular}{|c|c|c|c|c|c|}
\hline \multirow[t]{2}{*}{$\mathrm{S} / \mathrm{n}$} & \multirow[t]{2}{*}{ Bacterial Isolates } & \multicolumn{4}{|c|}{ Zones of Inhibition for Control and Experimental fish mucus (mm) } \\
\hline & & $\begin{array}{c}\text { Experimental } \\
\text { Tanks (Control) }\end{array}$ & $\begin{array}{l}\text { Epidermal mucus } \\
\text { of Control fish }\end{array}$ & $\begin{array}{c}\text { Experimental } \\
\text { Tanks (Treatment) }\end{array}$ & $\begin{array}{l}\text { Epidermal mucus } \\
\text { of Treatment fish }\end{array}$ \\
\hline \multirow[t]{3}{*}{1} & Staphylococcus & Tank A & 8.8 & Tank B & 26.4 \\
\hline & & Tank $A_{1}$ & 9.2 & Tank $B_{1}$ & 25.7 \\
\hline & & Tank $\mathrm{A}_{2}$ & 9.1 & Tank $\mathrm{B}_{2}$ & 26.1 \\
\hline \multirow[t]{3}{*}{2} & Streptococcus & Tank A & 7.8 & Tank B & 18.5 \\
\hline & & Tank $A_{1}$ & 7.1 & Tank $B_{1}$ & 20.2 \\
\hline & & Tank $\mathrm{A}_{2}$ & 6.9 & Tank $\mathrm{B}_{2}$ & 19.3 \\
\hline \multirow[t]{3}{*}{3} & Escherichia & Tank A & 11.0 & Tank B & 30.3 \\
\hline & & Tank $A_{1}$ & 11.1 & Tank $B_{1}$ & 28.7 \\
\hline & & Tank $A_{2}$ & 11.4 & Tank $B_{2}$ & 30.0 \\
\hline \multirow[t]{3}{*}{4} & Bacillus & Tank A & 24.7 & Tank B & 31.3 \\
\hline & & Tank $A_{1}$ & 26.1 & Tank $B_{1}$ & 30.8 \\
\hline & & Tank $\mathrm{A}_{2}$ & 24.3 & Tank $B_{2}$ & 29.9 \\
\hline
\end{tabular}

Table 3. Results of analysis of zones of inhibition of epidermal mucus of control and treatment fish

\begin{tabular}{llll}
\hline S/n & Bacteria isolates & T Statistics & T Critical \\
\hline 1 & Staphylococcus & -53.5674 & 4.302653 \\
2 & Streptococcus & -16.9336 & 4.302653 \\
3 & Escherichia & -37.5034 & 4.302653 \\
4 & Bacillus & -10.266 & 4.302653 \\
\hline
\end{tabular}

T test: Paired Two Sample Means (two-tailed). 


\section{Discussion}

The role of epidermal mucus as an important component of fish innate immunity was demonstrated in this study with fish epidermal mucus being a potential source of antimicrobial activity for specific fish pathogens. This fact is evidenced by the clear zones of inhibition observed for the epidermal mucus of the control fish signifying absence of bacterial growth thereby indicating that fish mucus has antimicrobial properties which prevented bacterial growth. This fact could be attributed to a complex system of innate defence mechanisms enabling fish epidermal mucus to have a potential broad spectrum-antimicrobial activity. Balasubramanian, Baby, Arul, Prakash, Senthilraja and Gunasekaran (2012) noted that despite an intimate contact with high concentrations of pathogens (bacteria and viruses) in their environment, the fish can still maintain a healthy system under normal conditions. Fish skin is a complex limiting structure providing mechanical, chemical and immune protection against injury and pathogenic micro-organisms (Fontenot \& Neiffer, 2004). Many researchers have proved that mucus exhibits good resistance to invading pathogens (Fletcher, 1978; Ingram, 1980; Austin \& McIntosh, 1988; Fouz, Devaja, Gravningen, Barija, \& Tranzo, 1990). Fish mucus layer confers an innate immune protection against pathogen entry. Mucus covering fish surfaces exposed to water acts as an innate and adaptive first line of defence against pathogen entry (Shephard, 1994).

In fish, the epidermal mucus is considered a key component of innate immunity. The composition and rate of mucus secretion has been observed to change in response to microbial exposure or to environmental fluctuations (Ellis, 2001). Raj et al. (2011) reported that skin mucus removal and epidermal lesions in Cyprinus carpio in invitro experiments enhanced the entry of CyHV-3 virus while the presence of skin mucus of Cyprinus carpio conferred protection against the entry of the virus. Numerous studies on innate immunity in fish have shown that fish epidermal mucus can inhibit the growth of some bacteria and therefore may have a potential source of novel antimicrobial components in it (Wei, Xavier, \& Marimuthu, 2010). Kasai et al. (2009) observed inhibition of growth of Staphylococcus epidermidis and $S$. aureus and noted that the proliferation of S. epidermidis in particular was strongly suppressed, the effect being most marked among all the bacteria strains studied.

The antibacterial activity of fish mucus may be due to the presence of antibacterial glycoproteins which are able to kill bacteria by forming large pores in the target membranes (Ebran, Julien, Orange, Saglio, Lemaitre, \& Molle, 1999). Fish mucus is believed to play an important role in the prevention of colonization by parasites, bacteria and fungi and thus act as a chemical defence barrier (Gobinath \& Ravichandran, 2011).

Results show an antibiotic effect of ginger against isolates of bacteria in fish samples from cultured ponds. The antimicrobial role of ginger in improving protection of fish against bacterial infection was shown by the higher zones of inhibition observed for epidermal mucus extract of fish-fed ginger in diet when compared with epidermal mucus extract of control fish. Dugenci, Arda and Candan (2003) have shown that the rainbow trout fish fed with diets containing aqueous extracts of mistletoe (Viscum album), nettle (Urtica dioica), and ginger (Zingiber officinale) exhibited significant non-specific immune responses. Pandy (2013) also reported that all medicinal plants are able to stimulate only non-specific immune responses and suggested that vaccines might be a better way to prevent deadly diseases and as such the plants could be used as vaccine adjuvant. In addition, Idris, Omojowo, Omojasola, Adetunji and Ngwu (2010) while working on the effect of different concentrations of ginger on smoked-dried C. gariepinus, found that ginger reduced the free fatty acid values, trimethylamine values as well as reduced the fungi load of processed fish. The antimicrobial action of ginger has also been reported by Patel, Thaker and Patel (2011) in invitro studies using ginger in combination with honey against Staphylococcus isolates. Ginger definitely has antimicrobial properties and its use in the prevention of emergence of resistant bacteria is of high benefit.

\section{Conclusion}

This study has demonstrated the antibacterial role of fish mucus as shown by the higher zones of inhibition observed for mucus extract of fish-fed ginger in diet as against inhibition zones of mucus extract of fish without ginger in diet. The addition of ginger in C. gariepinus diet is encouraged as its action is indicative of the potentials of ginger in preventing emergence of resistant bacteria. Ginger inclusion in fish diet is beneficial in improving the antimicrobial role of fish mucus and hence the quality of $C$. gariepinus.

\section{References}

Austin, B., \& Mclntosh, D. (1988). Natural antibacterial compounds on the surface of rainbow trout. Journal of Fish Diseases, 11(3), 275-277. http://dx.doi.org/10.1111/j.1365-2761.1988.tb00550.x

Balasubramanian, S., Baby, R. P., Arul, P. A., Prakash, M., Senthilraja, P., \& Gunasekaran, G. (2012). Antimicrobial properties of skin mucus from four freshwater cultivable fishes (Catla catla, 
Hypophthalmichthys molitrix, Labeo rohita and Ctenopharyngodon idella). African Journal of Microbiology Research, 6(24), 5110-5120. http://10.1016/s1995-7645(11)60091-6

Bhalodia, N. R., \& Shukla, V. J. (2011). Antibacterial and antifungal activities from leaf extracts of Cassia fistula 1.: An ethnomedicinal plant. Journal of Advanced Pharmaceutical Technology \& Research, 2(2), 104-109. http://dx.doi.org/10.4103/2231-4040.82956

Cavalieri, S. J., Harbeck, R. J., McCarter, Y. S., Ortez, J. H., Rankin, I. D., Sautter, R. L., ... Spiegel, C. A. (2005). Manual of Antimicrobial Susceptibility Testing. Coordinating Editor, M. B. Coyle. American Society for Microbiology (ASM).

Du, X. Y., \& Clemetson, K. J. (2002). Snake venom L-amino acid oxidases. Toxicon, 40(6), 659-665. http://dx.doi.org/10.1016/S0041-0101(02)00102-2

Dugenci, S. K., Arda, N., \& Candan, A. (2003). Some medicinal plants as immune-stimulant for fish. Journal of Ethnopharmacology, 80, 99-106. http://dx.doi.org/10.1016/S0378-8741(03)00182-X

Ebran, N., Julien, S., Orange, N., Auperin, B., \& Molle, G. (2000). Isolation and characterization of novel glycoproteins from fish epidermal mucus: correlation between their poreforming properties and their $\begin{array}{lllll}\text { antibacterial activities. Biochim Biophys } & \text { 271-280. }\end{array}$ http://dx.doi.org/10.1016/S0005-2736(00)00225-X

Ebran, N., Julien, S., Orange, N., Saglio, P., Lemaitre, C., \& Molle, G. (1999). Pore forming properties and antibacterial activity of protein extracted from epidermal mucus of fish. Comparative Biochemical Physiology A, 122, 181-189. http://dx.doi.org/10.1016/S1095-6433(98)10165-4

Ellis, A. E. (2001). Innate host defence mechanisms of fish against viruses and bacteria. Dev. Comp. Immunol., 25, 827-839. http://dx.doi.org/10.1016/S0145-305X(01)00038-6

Fletcher, T. (1978). Defense mechanisms in fish. In D. Malins \& J. Sargent (Eds.), Biochemical and Biophysical perspertives in marine biology (pp. 189-222). London: Academic Press.

Fontenot, D. K., \& Neiffer, D. L. (2004). Wound management in teleost fish: biology of the healing process, evaluation and treatment. Vet. Clin. North Am. Exot. Anim. Pract., 7, 57-86. http://dx.doi.org/10.1016/j.cvex.2003.08.007

Fouz, B., Devaja, S., Gravningen, K., Barija, J. L., \& Tranzo, A. E. (1990). Antibacterial action of the mucus of the turbot. Bulletin European Association of Fish Pathology, 10, 56-59.

Gobinath, R. A. C., \& Ravichandran, S. (2011). Antimicrobial peptide from the epidermal mucus of some estuarine cat fishes. World Applied Sciences Journal, 12(3), 256-260.

Hjelmeland, K., Christe, M., \& Raa, J. (1983). Skin mucus protease from rainbow trout, Salmo gairdlneri, Richardson and it's biological significance. Journal of Fish Biology, 23(1), 13-22. http://dx.doi.org/10.1111/j.1095-8649.1983.tb02878.x

Idris, G. L., Omojowo, F. S., Omojasola, P. F., Adetunji, C. O., \& Ngwu, E. O. (2010). The effect of different concentrations of ginger on the quality of smoked-dried catfish (Clarias gariepinus). Nature and Science, $8(4), 59-63$.

Ingram, G. A. (1980). Substances involved in the natural resistance of fish to infection - A Review. Journal of Fish Biology, 16, 23-60. http://dx.doi.org/10.1111/j.1095-8649.1980.tb03685.x

Jung, S. K., Mai, A., Iwamoto, M., Arizono, N., Fujimoto, D., Sakamaki, K., \& Yonehara, S. (2000). Purification and cloning of an apoptosis-inducing protein derived from fish infected with Anisakis simplex, a causative nematode of human anisakiasis. Journal of Immunology, 165, 1491-1497.

Kanno, T., Nakai, T., \& Maroga, K. (1989). Mode of Transmission of vibrios among ayu Plecoglossus activelis. Journal of Aquatic Animal Health, $1(1), \quad 2-6$. http://dx.doi.org/10.1577/1548-8667(1989)001\%3C0002:MOTOVA\%3E2.3.CO;2

Kasai, K., Ishikawa, T., Komata, T., Fukuchi, K., Chiba, M., Nozaka, H., ... Miura, T. (2009). Novel 1-amino acid oxidase with antibacterial activity against methicillin-resistant Staphylococcus aureus isolated from epidermal mucus of the flounder Platichthys stellatus. Biochemistry FEBS Journal, 277(2), 453-465. http://dx.doi.org/10.1111/j.1742-4658.2009.07497.x

Kitani, Y., Kikuchi, N., Zhang, G., Ishizaki, S., Shimakura, K., Shiomi, K., \& Nagashima, Y. (2008). Antibacterial action of L-amino acid oxidase from the skin mucus of rockfish Sebastes schlegelii. 
Comparative Biochemical Physiology B: Biochemistry and Molecular Biology, 149, 394-400. http://dx.doi.org/10.1016/j.cbpb.2007.10.013

Kitani, Y., Tsukamoto, C., Zhang, G., Nagai, H., Ishida, M., Ishizaki, S., ... Nagashima, Y. (2007). Identification of an antibacterial protein as L-amino acid oxidase in the skin mucus of rockfish Sebastes schlegeli. Biochemistry FEBS Journal, 274(1), 125-136. http://dx.doi.org/10.1111/j.1742-4658.2006.05570.x

Kuppulakshmi, C., Prakash, M., Gunasekaran, M. G., Manimealai, G., \& Sarojini, S. (2008). Antibacterial properties of fish mucus from Channa punctatus and Cirrhinus mrigala. European Review for Medical and Pharmacological Sciences, 12, 149-153

MacFaddin, J. F. (1980). Biochemical Tests for Identification of Medical Bacteria (2nd edition) (p. 313). Baltimore: The Williams and Wilkins Co..

Muroga, K., Higashi, M., \& Keitoku, H. (1987). The isolation of intestinal microflora of farmed red seabream (Pagrus major) and black seabream (Acanthopagrus schlegeli) at larval and juvenile stages. Aquaculture, 65, 79-88. http://dx.doi.org/10.1016/0044-8486(87)90272-9

Noya, M., Magarinos, B., Toranzo, A. E., \& Lamas, J. (1995). Sequential pathology of experimental pasteurellosis in gilthead seabream sparus aurata a light microscopic and electron microscopic study. Diseases of Aquatic Organisms, 21,177-186. http://dx.doi.org/10.3354/dao021177

Nwabueze, A. A. (2011). Public Health Implications of Aquatic Snails around Fish Ponds in Okwe, Delta State. International Journals of Agriculture and Rural Development (IJARD), 14(2), 652-656.

Nwabueze, A. A. (2012). Diseases Status of Clarias gariepinus (Burchell, 1822) and Some Fish Ponds in Asaba, Nigeria. International Journal of Agriculture and Rural Development, 15(3), 1216-1222.

Obara, K., Otsuka-Fuchino, H., Sattayasai, N., Nonomura, Y., Tsuchiya, T., \& Tamiya, T. (1992). Molecular cloning of the antibacterial protein of the giant African snail, Achatina fulica Férussac. European Journal of Biochemistry, 209, 1-6. http://dx.doi.org/10.1111/j.1432-1033.1992.tb17254.x

Pandy, G. (2013). Some medicinal plants to treat fish ectoparasitic infections. International Journal of Pharmaceutical and Research Sciences (IJPRS), 2(2), 532-538.

Patel, R. V., Thaker, V. T., \& Patel, V. K. (2011). Antimicrobial activity of ginger and honey on isolates of extracted carious teeth during orthodontic treatment. Asian Journal of Tropical Biomedicine, 558-561.

Patrick-Iwuanyanwu, K. C., Wegwu, M. O., Ayalogu, E. O. (2007). The protective nature of garlic, ginger and vitamine C on CCl4-induced hepatotoxicity in rats. Asian Journal of Biochemistry, 2(6), 409-414. http://dx.doi.org/10.3923/ajb.2007.409.414

Raj, S. T., Fournier, G., Rakus, K., Ronsmana, M., Ouyang, P., Michel, B., ... Vanderplasschen, A. (2011). Skin mucus of Cyprinus carpio inhibits cyprinid herpesvirus 3 binding to epidermal cells. Veterinary Research, 42, 92. http://dx.doi.org/10.1186/1297-9716-42-92

Shephard, K. L. (1994). Functions for fish mucus. Reviews in Fish Biology \& Fisheries, 4, 401-429. http://dx.doi.org/10.1007/BF00042888

Stoll, G. (2000). Natural crop protection in the tropics. Margraf Verlag, Weikersheim.

Subramanian, S., Mackinnon, S. L., \& Ross, N. W. (2007). A comparative study on innate immune parameters in the epidermal mucus of various fish species. Comparative Biochemical Physiology, 148B, 256-263. http://dx.doi.org/10.1016/j.cbpb.2007.06.003

Wei, O. Y., Xavier, R., \& Marimuthu, K. (2010). Screening of antimicrobial activity of mucus of Snakehead fish, Channa striatus (Bloch). European Review for Medical and Pharmacological Sciences, 14, 675-681.

\section{Copyrights}

Copyright for this article is retained by the author(s), with first publication rights granted to the journal.

This is an open-access article distributed under the terms and conditions of the Creative Commons Attribution license (http://creativecommons.org/licenses/by/3.0/). 